\title{
FROM BARRIER TO BRIDGE: RECONFIGURING THE IRISH BORDER AFTER THE BELFAST GOOD FRIDAY AGREEMENT
}

\author{
Cathal McCall, Institute of Governance, Queen's University \\ Belfast*
}

"If an institution is to be an institution, it must to some extent break with the past, keep the memory of the past, while inaugurating something absolutely new."1

\section{INTRODUCTION}

Twenty years ago, John Whyte made what he termed a 'preliminary reconnaissance' of the Irish border's permeability. He noted a multitude of organisations existing on an all-island basis including churches and church related groups, youth and sporting groups, cultural and scientific organizations, charitable and welfare organizations, professional associations, as well as business, banking, media and arts concerns. ${ }^{2}$ His extensive inventory of private cross-border organisations was in stark contrast to the absence of a cross-border dimension to public life on the island after partition. Dennis Kennedy has commented that,

"One of the most remarkable features of the history of the island over the past seventy five years has been, at government level, the near totality of partition, the replacement of a long established single administrative system by two separate administrative systems, which managed, or contrived, to keep all contact to a minimum, which built no new structures, however modest, to take care of common interests in practical matters and which for many decades had no dialogue at all at political level." 3

However, the absence of cross-border co-operation at the political level for almost eighty years disguises the fact that numerous attempts were made at establishing such co-operation.

* I wish to thank Professor Liam O'Dowd, Professor Tom Wilson, Dr Gillian McIntosh and participants in the workshop for comments on an earlier draft. The usual disclaimer applies.

1 J Derrida, Deconstruction in a Nutshell: A Conversation with Jacques Derrida (1997) p 6.

2 Whyte also noted that many organizations, particularly charitable and welfare organizations and professional associations are organized on an East-West (BritishIrish) basis. For example, the Royal National Lifeboat Institution and the Association of Certified Accountants (in J Whyte, 'The Permeability of the United Kingdom-Irish Border: A Preliminary Reconnaissance', (1983) 31 Administration 330).

3 D Kennedy, 'Politics of North-South Relations in post-Partition Ireland' in P J Roche and B Barton (eds), The Northern Ireland Question: Nationalism, Unionism and Partition (1999) p 71 at 73. 
The Government of Ireland Act (1920) made provision for a cross-border Council of Ireland to act as an institutional bridge between the two devolved parliaments in Ireland, one in the North and one in the South. In the event, political aspirations, political violence and state-building, North and South, took precedence and the Council of Ireland was still-born. The Craig/Collins Pacts of 1922 held out the hope of sustained cross-border political cooperation between Northern Ireland and the Irish Free State. ${ }^{4}$ However, the apparent duplicity of Michael Collins, head of the provisional government in the South (with Arthur Griffith), and on-going political and sectarian violence in the North ${ }^{5}$ scuttled the pacts. ${ }^{6}$ Thereafter, the border became an increasingly entrenched political barrier between North and South.

After the cold war between North and South, which lasted from the 1930s to the 1960s and was stimulated in large part by Eamon de Valera's 1937 Bunreacht na hÉireann (Irish constitution), ${ }^{7}$ rumblings of a renewed attempt at cross-border co-operation were felt in the 1960s under the auspices of the Lemass/O'Neill rapprochement. However, the initiative of the then Taoiseach Seán Lemass and Northern Ireland Prime Minister Captain Terence O'Neill also foundered. Traditionalist unionist forces mustered successfully to stop O'Neill's attempt at establishing cross-border cooperation for the socio-economic advancement of Northern Ireland. In 1974, the attempted resuscitation of the Council of Ireland model, to complement the power-sharing Northern Ireland Executive, intensified the Ulster unionist/loyalist backlash against power-sharing with Irish nationalists in Northern Ireland. The backlash, in the form of a general strike, was to scupper the second coming of the Council and terminate the life of the Executive after five months operation.

These successive attempts at establishing North/South political co-operation proved to be not only unfruitful, they also served to buttress the border so that it acted as an effective barrier between North and South. Therefore, in light of an eighty-year experience of failed attempts at establishing crossborder co-operation and consequent re-enforcement of the border as a barrier, it is remarkable that the Belfast Good Friday Agreement (1998), whose provisions were given legal force by the Northern Ireland Act (1998), survived the establishment and operation of the North/South Ministerial Council and its Implementation Bodies. It is even more remarkable that these North/South institutions, which facilitate co-operation and co-

4 The Irish state has existed in different forms and under different names. The Irish Free State was changed to 'Éire' (Ireland) in de Valera's 1937 constitution which also ended dominion status. Éire became a republic in 1949 with the enactment of the Republic of Ireland Act (1949) and the symbolic declaration of a republic on Easter Monday 1949. More recently, the Republic of Ireland has been referred to simply as 'Ireland', as in McGimpsey v Ireland [1990] ILRM441, and in the Belfast Good Friday Agreement (1998), suggesting a twenty-six county statist conception of Ireland.

5 Between December 1921 and May 1922 there were 236 fatalities.

6 D Fitzpatrick, The Two Irelands (1998); P Buckland, 'A Protestant State: Unionists in Government, 1921-39' in D G Boyce and A O'Day (eds), Defenders of the Union: A Survey of British and Irish Unionism Since 1801 (2001) p 211 at 212.

7 The 1937 Irish constitution not only ended the Free State's dominion status, it also gave special position to the Catholic Church in Éire and reiterated its territorial claim over the whole island. 
ordination between the North and South, have proven to be one of the Agreement's least controversial provisions.

This article examines why efforts made to establish cross-border cooperation failed in the past when such co-operation succeeds, albeit tentatively and intermittently, in the present. The article considers: past failures; the dynamics that have encouraged contemporary North/South cooperation; the processes that have established the architecture for cooperation; the manifestation of the border as a bridge; and the prospects for the development of co-operation by the North/South institutions in a political climate that continues to be inter-communally competitive and highly volatile.

\section{Past Failures}

The Government of Ireland Act (1920) provided for a Council of Ireland to promote North/South co-operation. At the second reading of the Bill on 29 March 1920, James Macpherson (Chief Secretary for Ireland) claimed that the Council of Ireland could become 'virtually a Parliament for all Ireland, and from that stage to complete union is but a very slight and very easy transition'. ${ }^{8}$ Section 2(1) of the 1920 Act outlined the functions of the Council as: facilitating harmonious action between the two parliaments; promotion of a common approach to all-island matters; and the administration of services which were amenable to an all-island approach. ${ }^{9}$ However, the Council was paralysed by its vagueness as constituted in the 1920 Act. The dynamics of divergent political aspirations, violence and state-building on both sides of the border conspired to render its paralysis terminal. ${ }^{10}$ Unionist leaders were preoccupied with having to establish a government and parliament in the North that was foisted upon them and for which they had little time to prepare. ${ }^{11}$ For the Dublin government, meanwhile, the Council of Ireland was a non-starter because participation would symbolize its recognition of the Northern parliament.

The Craig/Collins Pacts of 1922 represented a more promising initiative for North/South co-operation because of their high-level political nature. The Pacts between Collins and Sir James Craig, the first Prime Minister of Northern Ireland, had the potential to avoid the retreat of Ulster into narrow territorial/cultural confines because they held out the hope of overcoming the creation of the border as a barrier. One of the terms of the first Pact that Collins and Craig agreed was: 'The two governments to endeavour to devise a more suitable system than the Council of Ireland for dealing with problems affecting all Ireland'. ${ }^{12}$ Their co-operative objective suggested the possibility of creating the border as a political, economic, cultural and intellectual bridge between Northern Ireland and the Irish Free State.

8 HC Deb, 127, cols 928-30, 29 March 1920.

9 B Hadfield, 'The Northern Ireland Constitution' in B Hadfield (ed), Northern Ireland: Politics and the Constitution (1992) p 1 at 2.

10 E Tannam, Cross-Border Cooperation in the Republic of Ireland and Northern Ireland (1999).

11 P Buckland, op cit n 6, 212.

12 Irish Times, 22 January 1922. 
The creation of an intellectual bridge would have been potentially valuable for Ulster unionism, especially when one considers its ensuing decades of political, intellectual and cultural stagnation after the formation of Northern Ireland. ${ }^{13}$ It has been claimed that internal divisions between reformers and hard-liners in Dublin, as much as Northern self-interest, were responsible for the extinction of Southern unionism. ${ }^{14}$ Nevertheless, the Irish landed gentry, supplying political reformers like Lord Midleton and Sir Horace Plunkett, as well as intellectuals like William Edward Hartpole Leckey and Edward Dowden at Trinity College, Dublin, were important political and intellectual pillars of unionism. According to Alvin Jackson, 'Irish Toryism supplied much of the organizational infrastructure around which unionism was constructed; and supplied trained advocates to the loyalist cause' ${ }^{15}$ Irish cultural revivalists like Standish O'Grady and $Æ$ were also sympathetic to the cause of Irish unionism. Therefore, the political, intellectual and cultural remnants of Southern Irish unionism remained valuable and worthy of maintenance. Such maintenance, if undertaken, could have provided the new Ulster unionist identity with a rich source of political, intellectual and cultural sustenance.

For a time, the Pacts enabled Collins to become the effective representative of Northern Catholics, especially Belfast Catholics. ${ }^{16}$ It is possible that, had they succeeded, the Pacts could also have lead to some form of Northern representation for Southern unionists. Craig's practical incentive for cooperation was the possibility of recognition by the Free State government. Craig believed that co-operation would provide the opportunity for securing the principle of consent in North/South relations, that is, that the consent of the unionist community would be required for 'Ulster' to join the Irish Free State. ${ }^{17}$ However, despite the first Pact, Collins continued his pursuit of a non-recognition policy regarding Northern Ireland. ${ }^{18}$ Simultaneously, the Irish Republican Army (IRA), with help and encouragement from Collins, continued to engage in violence north of the border. A second Pact was entered into by the two leaders in an attempt to end violence and reform the police in Belfast. That Pact too foundered, primarily because of the failure of the Northern government to investigate the alleged role of policemen in sectarian murder in Belfast. ${ }^{19}$

The manifestation of the border as a bulwark against the Irish Free State won out and came to embody the unionist perception of threat emanating from its Irish nationalist 'Other'. The Boundary Commission (1925), which was

13 P Bew, 'The Political History of Northern Ireland Since Partition: The Prospects for North-South Co-operation' in A F Heath, R Breen and C T Whelan (eds), Ireland North and South (1999) p 401 at 411.

14 A Jackson, 'The Failure of Unionism in Dublin, 1900' (1989) 26 Irish Historical Studies 377.

15 A Jackson, 'Irish Unionism, 1879-1922' in D G Boyce and A O'Day (eds), Defenders of the Union: A Survey of British and Irish Unionism Since 1801 (2001) p 115 at 116.

16 Kennedy op cit n 3, 80.

17 Bew op cit $\mathrm{n} 13,407$.

18 Ibid, 408

19 M Farrell, Arming the Protestants: The Formation of the Ulster Special Constabulary and the Royal Ulster Constabulary 1920-27 (1983), pp 114-117. 
proposed in the Anglo-Irish Treaty (1921), presented Ulster unionists with the immediate threat of losing territory to the Irish Free State, a threat that failed to materialize. ${ }^{20}$ However, other threats proved to be more durable and served to buttress the manifestation of the border as a barrier. The Irish state's constitutional claim to the six counties of Northern Ireland persisted until the Belfast Good Friday Agreement (1998) and fuelled the sense of territorial siege in the Ulster unionist communal imagination. That the 1937 constitution reasserted the claim and also recognized the special position of the Catholic Church in the Irish state was hardly an inducement for Ulster unionists to reconsider their attitude to Éire and the border. ${ }^{21}$

The threat from perfide Albion also arose periodically. An example of United Kingdom (UK) government perfidy occurred in 1940 when Churchill offered de Valera Irish unity as an incentive for granting Allied troops permission to use Southern ports. Set against the unionist self-perception as a loyal wartime subject community and the reaffirmation of Irish nationalist disloyalty through the declaration of Éire neutrality, knowledge of the offer to de Valera served to heighten the sense of threat experienced by the Ulster unionist community. ${ }^{22}$ The violent campaign of the IRA presented a recrudescent physical threat that was intimately associated with the border in ideological and practical terms. Consequently, devoid of political and intellectual adroitness, the combined effect of these constitutional, perfidious and physical threats, emanating from Dublin, Westminster and the IRA respectively, set Ulster unionism on a course characterized by isolationism, defensiveness, vulnerability and insecurity. The cultural chasm that existed between unionists and Éire, especially after the 1937 Irish constitution, helped to reinforce that sense of threat.

In the post-World War II period, occasional verbal broadsides were fired from the North across the border. In 1949, St John Ervine published his 'semi-official' biography of James Craig in which he took the liberty of launching vitriolic diatribes directed at the Republic of Ireland and its citizens. ${ }^{23}$ According to Gillian McIntosh, 'Ervine's biography can be seen as having provided a necessary pressure valve, providing unionists with a high-profile outlet for their feelings towards contemporary events, and an articulation of some of their genuinely held but, at the time, politically sensitive beliefs' ${ }^{24}$ For Basil Brooke, the then Prime Minister of Northern Ireland, the transition of Éire to a republic was 'the last stage of that deplorable journey'. ${ }^{25}$

While overt cross-border contact at a political level had proven to be impossible for four decades after the Craig/Collins Pacts, some covert contact did take place, for example, Sean MacBride (the Republic's Minister

20 D Kennedy, The Widening Gulf: Northern Attitudes to the Independent Irish State (1988) p 73.

21 Buckland op cit $\mathrm{n}$ 6, pp 220-1.

$22 \mathrm{G}$ McIntosh, The Force of Culture: Unionist Identities in Twentieth-Century Ireland (1999) p 145.

23 Ibid, $\mathrm{p} 154$

24 Ibid, 156.

25 Kennedy op cit n 20, p 239. 
for External Affairs) met Sir Basil Brooke twice. ${ }^{26}$ More concrete practical, low-level co-operation was achieved during the 1950s with: the agreement on the Erne (1950); the creation of the Foyle Fisheries Commission (1952); and the subsequent establishment of the Great Northern Railway Board. ${ }^{27}$ However, high-level political talks resumed eventually with two meetings in the 1960s between Republic of Ireland Taoiseach Seán Lemass and Northern Ireland Prime Minister Captain Terence O’Neill.

After becoming Taoiseach in 1958, Seán Lemass embarked on a charm offensive directed at Ulster unionists. His intention was to soften an Irish border that had become a well-fortified barrier after the introduction of the 1937 Irish constitution. A turning point came in July 1963 when, in reference to Northern Ireland, Lemass declared that, 'the government and parliament there exists with the support of the majority in the six counties area, artificial though that area is. We see it functioning within its powers. . . within an all Ireland constitution, for as long as it is desired by them'. ${ }^{28}$ This qualified recognition of Northern Ireland was enough to stir the interest of O'Neill in Lemass' call for North/South discussions. However, subsequent anti-partitionist speeches by Lemass in the United States made O'Neill baulk from immediate face-to-face discussions. It wasn't until Brian Faulkner (a minister in O'Neill's cabinet) offered to meet Jack Lynch, Faulkner's opposite number in the Republic of Ireland, that O'Neill moved to meet Lemass at Stormont on 17 January 1965, with a return visit to Dublin on 9 February. ${ }^{29}$ Problematically for O'Neill, he failed to inform most of his cabinet colleagues about the first meeting, leaving traditionalists free to suspect or claim double-dealing. Moreover, Lemass tended to link economic co-operation to political co-operation and the ending of partition. While this linkage in itself may not have been a problem for O'Neill, its timing was. Eventually, pressure from the Reverend Ian Paisley and the threat of revolt from within the ruling ranks of the Unionist Party ran aground the Lemass/O'Neill rapprochement. Furthermore, the increase in tension with the 1966 commemoration of the 1916 Easter Rising and the rise to prominence of the Civil Rights campaign effectively halted the attempt at bridge-building. ${ }^{30}$ Paisley used his skills as a populist communicator to particular effect when, in reference to the dry and aloof O'Neill, he railed: 'he is a bridge builder he tells us. A traitor and a bridge are very much alike for they both go over to the other side'. ${ }^{31}$

The Sunningdale Agreement of December 1973 offered renewed hope for the re-creation of the border as a bridge. A new Council of Ireland was proposed as a supplement to a Northern Ireland power-sharing system of government which had been provided by the Northern Ireland Constitution Act (1973). This Council of Ireland was to comprise of a Council of Ministers with seven members each drawn from the Northern and Southern

26 P Arthur, Special Relationships: Britain, Ireland and the Northern Ireland Problem (2000) p 8.

27 Kennedy op cit $\mathrm{n} 3, \mathrm{p} 84$.

28 Quoted in M Mulholland, Northern Ireland at the Crossroads: Ulster Unionism in the O'Neill Years, 1960-9 (2000) p 80.

${ }^{29}$ Ibid, $\mathrm{p} 82$.

30 Kennedy op cit $\mathrm{n} 3, \mathrm{p} 85$.

31 Quoted in Mulholland op cit $\mathrm{n} 28,84$. 
governments. The Council was to be invested with an executive and harmonizing function as well as a consultative role. Decisions were to be passed by unanimous vote. A Consultative Assembly, comprising thirty members each from the Northern Ireland Assembly and Dáil Éireann was proposed to perform advisory and review functions. ${ }^{32}$ For the Irish government, the proposed Council of Ireland represented a means of promoting unification. However, the new cross-border/all-island institution proved to be unpalatable for a majority of unionists who viewed it much as the Irish government did. The Ulster Workers' Council strike of 1974 not only stifled its creation, the strike also collapsed the entire edifice of powersharing government in Northern Ireland after just five months operation.

\section{Contemporary Dynamics}

A year previously, the UK and Republic of Ireland acceded to the European Economic Community (EEC). From their accession to the EEC in 1973, the governments of the Republic of Ireland and UK enjoyed increasing levels of maturity in their relationship, a relationship that was based on increasing mutual respect and partnership. EEC/EC/EU membership created the opportunity for the Irish economy to diversify and expand, thus transcending its reliance on UK markets. EU membership also enabled the Irish state to achieve formal equality with the UK state in an international arena. Consequently, the relationship between the two states shifted from one founded on dominance and dependence to one based on equality and interdependence. ${ }^{33}$ Furthermore, the neutral arena of the EC/EU enabled UK and Irish politicians and diplomats to escape the claustrophobic territorial confines of the British Isles and a British-Irish relationship forged in antagonism and conflict. Bilateral meetings became commonplace on the fringes of EU meetings, particularly European Council meetings which involved the Irish Taoiseach and the UK Prime Minister. The recast relationship that developed was especially valuable for the Northern Ireland problem because it became an international partnership of equals that was beyond the destructive grasp of regionally confined Ulster unionists.

The European context facilitated rounds of Anglo-Irish summitry beginning in 1980 and provided the space for the fledgling Anglo-Irish intergovernmental relationship that involved leading politicians and Cabinet officials. The fledgling relationship faltered at times, for example after the Argentinian invasion of the Falklands/Malvinas on 2 April 1982. However, in December 1984, Mrs Thatcher and Irish Taoiseach Garret Fitzgerald met at an EC summit in Dublin. The meeting reopened a line of communication between British and Irish officials responsible for the Anglo-Irish process, a process aided by US political and media interest. ${ }^{34}$ The subsequent AngloIrish Agreement (1985) gave the Irish government a role in Northern Ireland affairs, a role that has been described as being 'more than consultative, but

32 Hadfield op cit n 9, p 8; T Hennessey, A History of Northern Ireland, 1920-1996 (1997) p 221.

33 P Arthur op cit $\mathrm{n}$ 26, p 129; C McCall, 'The Production of Space and the Realignment of Identity in Northern Ireland' (2001) 11 Regional and Federal Studies 1.

34 A Guelke, Northern Ireland: The International Perspective (1988); Arthur op cit $\mathrm{n}$ 26, p 217. 
less than executive'. ${ }^{35}$ Mrs Thatcher's motive for signing the Agreement was undoubtedly heavily influenced by security concerns. However, cabinet colleagues and civil servants impressed upon her the need to place security measures in the context of an overall package that included an Irish dimension. ${ }^{36}$ The effect of the Anglo-Irish Agreement was that the Irish government became a minor partner of the UK government in the exercise of joint authority over Northern Ireland. Observing its innovative nature, one Irish academic lawyer commented that 'it will be seen by international lawyers as an important new legal model for consideration, adaptation and possible application in other similar international situations of disputed sovereignty over territory'. ${ }^{37}$

Meanwhile, at the macro-European level, the Single European Act (1987) provided for the completion of the Single European Market by 1992. The ensuing economic, political and cultural processes of Europeanization began to pose serious questions for UK state sovereignty and the manifestation of the Irish border as a barrier. The developing EC presented a challenge to the legal sovereignty of the national/nation-state and threatened an increasing challenge to its political sovereignty. Member states either embraced or acquiesced in this transference or 'pooling' of sovereignty in response to the contemporary economic, political and social challenges of globalization/internationalization. After 1985, there was a dramatic increase in the frequency of Intergovernmental Conferences (IGCs) which translated into a frenetic bout of EU constitution-building. IGC treaty-making resulted in changing the decision-making rules that have enabled the EU to increase its policy-making capacity. Consequently, the entrepreneurial Commission, driven by its federalist President, Jacques Delors, moved the EC/EU into key areas of state activity and highlighted the fact that west European borders were being made more permeable by the process of Europeanization. ${ }^{38}$

The antipathy of unionist political élites to these European developments was compounded by the general Euro-enthusiasm of Irish nationalists. In particular, unionist leaders understood the articulation of 'post-nationalism' and a 'Europe of the Regions', by the then Social Democratic and Labour Party (SDLP) leader, John Hume, as a cunning ploy used to disguise Irish nationalist irredentist ambition. Consequently, Europeanization was regarded by Ulster unionist élites as little more that a supplementary weapon in the Irish nationalist anti-partitionist canon. Furthermore, the Anglo-Irish Agreement (1985), which brought an infringement of sovereignty directly to the Irish border, had traceable Euro-roots which could only strengthen unionist antipathy to the development of the EC/EU.

Unionist anger at the imposition of the Anglo-Irish Agreement, without their consent, was compounded by their powerlessness in the face of its implementation. Moreover, Ulster unionists were presented with an array of inter-related contemporary dynamics which militated against their traditional ideological position of exclusion regarding Irish nationalists/republicans in

35 By the then Irish Taoiseach, Garret Fitzgerald.

36 D Goodhall, 'The Irish Question' (1993) Ampleforth Journal, vol. XCVIII, 129.

37 J O'Conner in the Irish Times, 21 November 1985.

38 J Caporaso, 'The European Union and Forms of State: Westphalian, Regulatory and Post-Modern' (1996) 34 Journal of Common Market Studies 29. 
the governance of Northern Ireland, and territorialism regarding state borders especially the border between Northern Ireland and the Republic of Ireland. These dynamics included: the loss of state power in 1972 after fifty years of unionist hegemonic rule in Northern Ireland; the transformed British-Irish intergovernmental relationship after 1973; the development of Europeanization and regionalization directly affecting borders in the British Isles; and a further modification in unionist-nationalist power relations after the signing of the Anglo-Irish Agreement in 1985. They required a new unionist approach to the Irish border and Irish nationalists. Eventually, unionist anger, coupled with the failure of subsequent extra-parliamentary 'Ulster Says No' boycotts, gave way to active engagement in political dialogue and political process during the early 1990s, an engagement that signalled a substantive milestone in the political process of reconfiguring the governance of Northern Ireland.

\section{Political Process}

After 1991, political talks on the future of Northern Ireland had a threestrand structure featuring Northern Ireland, North/South and British-Irish dimensions. Once again cross-border co-operation and the transformation of the Irish border from a barrier into a bridge was on the political agenda. Leaders of both the Ulster Unionist Party (UUP) and the Reverend Ian Paisley's Democratic Unionist Party (DUP) participated in these talks, which also involved the Irish government in a central co-ordinating role. The limitations of boycott and the importance of engagement in the political process were lessons learned by leaders from across the political spectrum of unionism. However, the idea of a political process clashes with the traditional unionist ideological preference for the status quo because 'process' implies change. ${ }^{39}$ Therefore, acceptance of the three-strand structure for talks did not necessarily translate into the acceptance of a political process leading to a three-strand structure for the governance of Northern Ireland that included formal North/South co-operation. Paisley was not about to do what he had accused O'Neill of trying to do twenty-five years earlier, namely, 'go over to the other side'. He and his party colleagues staged numerous walkouts during the talks process of the 1990s, exiting permanently on the arrival of Sinn Féin representatives into negotiations leading to the Agreement (1998). ${ }^{40}$ Nevertheless, leading representatives from the UUP and the smaller loyalist parties remained in the multi-party negotiations which lead to the Agreement.

The Agreement reflected the three-strand framework of the negotiations that preceded it. The framework encompassed the North/South [cross-border, island of Ireland] relationship, the east-west [or British-Irish] relationship, as well as the relationship between the Irish nationalist and Ulster unionist ethnonational communities within Northern Ireland. The complementary institutions provided by the Agreement included a Northern Ireland Executive, Assembly and Civic Forum, a North/South [cross-border, island

39 E Harris, 'Why Unionists are not Understood' in A Aughey et al, Selling Unionism (1995) p 27.

40 Sinn Féin joined the multi-party negotiations in September, 1994 after the IRA cease-fire. 
of Ireland] Ministerial Council and its Implementation Bodies, as well as a British-Irish Council and British-Irish Intergovernmental Conference. The Agreement nominally reaffirmed UK sovereignty over Northern Ireland in the formal-legal sense. However, these multifarious territorial and crossborder institutions helped to spread the political and cultural substance of sovereignty across a British, Northern Ireland, North/South, British-Irish and EU axis because each had autonomy, or potential autonomy in policymaking and administration. ${ }^{41}$ Henry Patterson has interpreted these arrangements as a 'constitutional triumph for unionism, combined with a certain political and ideological retreat'. ${ }^{42}$

Throughout the crises in the implementation of the Agreement, cross-border co-operation has remained relatively free from controversy. This is remarkable given the legacy of failed cross-border initiatives and the fact that a fleet of black Mercedes cars, in slow cavalcade, delivered the ministerial cabinet of the Irish government to the inaugural meeting of the North/South Ministerial Council, north of the border. The spectacle caused moderate northern nationalist representatives to blush because, in a region where symbolism has the potential to wreck painstakingly constructed initiatives, the implication of attendance at the wake of the Union was inescapable.

Peter Robinson (DUP, Deputy Leader) has, on occasion, attempted to inject a note of controversy on the issue of post-Agreement North/South cooperation. For example, in remarks to the 2002 annual conference of the Young Democrats, the DUP's youth wing, he claimed that the North/South bodies posed the 'greatest long-term threat' to the Union. ${ }^{43}$ However, the cross-border institutions stirred little controversy in the unionist community because issues of police reform and IRA decommissioning were more pressing concerns. The active involvement of leading Sinn Féin figures in the post-Agreement (1998) administration of Northern Ireland precluded a comparison with Collins' non-recognition policy. However, the IRA's retention of its arsenal and its continued intelligence gathering and training, as well as violent acts by dissident republicans, invited unionists to conclude some acquiescence by Sinn Féin in post-Agreement IRA activity that was reminiscent of Collins' support for an on-going IRA campaign north of the border while simultaneously agreeing pacts with Craig.

Pro-Agreement unionists may also have had some success in their presentation of the North/South institutions as being strictly under the control of the Northern Ireland Assembly and limited to practical low-level crossborder matters. Somewhat contrary to the pro-Agreement unionist interpretation, the North/South Ministerial Council was allocated a measure of autonomy in pursuit of its goals of co-operation and co-ordination providing agreement was reached among participants that include Ulster unionist representatives. However, decisions reached in the Council that are

41 J Ruane and J Todd, 'The Politics of Transition? Explaining Political Crises in the Implementation of the Belfast Good Friday Agreement' (2001) 49 Political Studies 923 at 936.

42 'From Insulation to Appeasement: The Major and Blair Governments Reconsidered' in R Wilford (ed), Aspects of the Belfast Agreement (2001) p 166 at 182

43 Irish Times, 18 February, 2002. 
'beyond the authority of those attending' require the consent of both the Oireachtas (Irish Parliament) and the Northern Ireland Assembly. ${ }^{44}$ Moreover, the refusal of UUP ministers to attend any North/South Ministerial Council meeting that included Sinn Féin members, which was announced on 21 September 2002, highlights the power of veto exercised by UUP élites over the recreation of the border as a bridge.

\section{The Border as a Bridge}

The North/South Ministerial Council represents the main architectural feature of the bridge between the Northern Ireland and the Republic of Ireland. It provides a forum for functional co-operation on aspects of transport, agriculture, education, health, the environment and tourism. In the Northern Ireland Programme for Government (2001) some of these aspects were identified, for example, in the area of education - educational underachievement, the mobility of teachers, and university co-operation were highlighted; in the area of health - cancer research, cross-border emergency planning and rapid response schemes were areas specified. ${ }^{45}$ European Structural Funds were singled out as a particularly important area for crossborder co-operation. Overtly Euro-federalist language was used in support of this co-operation - section 6.4, sub-priority 2 states: 'borders should not be barriers to balanced development across the European Territory'. In this regard, a 'Common Chapter' focusing on the development of North/South co-operation was agreed and is common to both the Structural Funds Plan for Northern Ireland and the National Development Plan for the Republic of Ireland. ${ }^{46}$

The North-South Ministerial Council has also begun to address the potentially important issue of opening a vertical line of communication to the European Commission regarding North/South interests. The Northern Ireland Assembly is bound by its devolved status from entering into international relations. However, the Northern Ireland Act (1998) does not withhold 'the exercise of legislative powers so far as required for giving effect to any agreement or arrangement entered into' (Section 55) in the North/South Ministerial Council or by or in relation to the North/South Implementation Bodies. ${ }^{47}$ Thus, the North/South institutions are free to conduct their transterritorial operations on an all-island and EU-wide basis. Such an exercise begins to address the ambiguous article in the Agreement (1998) which states: 'Arrangements to be made to ensure that the views of the [North/South Ministerial] Council are taken into account and represented appropriately at relevant EU meetings'. ${ }^{48}$

The other feature of North/South architecture is the North/South Implementation Bodies which concentrate on the specifics of co-operation regarding trade and business development, inland waterways, food safety, the Irish and Ulster-Scots languages, agriculture and marine matters, and

44 Agreement, 1998, strand 2, para 6

456.3 , Sub-priority 1.

46 www.northernireland.gov.uk/press/dfp/010620g-dfp.htm

47 B Hadfield, 'Seeing it Through? The Multifaceted Implementation of the Belfast Agreement' in R Wilford (ed), Aspects of the Belfast Agreement (2001) p 84 at 97.

48 Strand 2, para 17. 
special EU programmes. Some or all of these Implementation Bodies have the potential to become important nodes for cross-border and island of Ireland co-operation. However, mindful of the emphasis placed by the Northern Ireland Programme of Government on EU Structural Funds as an important area for North/South co-operation, special consideration is given below to this area and the role of the Special EU Programmes Body (SEUPB). As one of the North/South Implementation Bodies, SEUPB is charged with responsibility for the management of the EU PEACE II (20004) programme ${ }^{49}$ and Community Initiatives such as INTERREG III (20006)..$^{50}$ It has also been made responsible for the monitoring, promoting and implementation of the Common Chapter on cross-border co-operation. ${ }^{51}$

PEACE II forms part of a 'special package' under the Community Support Framework for Northern Ireland, which also includes the Transitional Objective 1 Structural Funds Programme worth $€ 890 \mathrm{~m}$ (stg£575m). ${ }^{52}$ PEACE II allocates approximately $€ 740 \mathrm{~m}$ to Northern Ireland and the border counties of the Republic of Ireland. The EU allocates $€ 530 \mathrm{~m}$ between 2000 4 with a further $€ 176 \mathrm{~m}$ coming from public sector funds and $€ 33 \mathrm{~m}$ from the private sector. ${ }^{53}$ PEACE II has five priority areas including economic renewal, social inclusion, locally based regeneration, the creation of an outward and forward-looking region, and cross-border co-operation. The cross-border co-operation priority has been allocated $€ 39.72 \mathrm{~m}$ (stg£24.45m) or 9.3 per cent of the total package in Northern Ireland and $€ 39.72 \mathrm{~m}$ in the border region of the Republic of Ireland. Between 2000-6, at least $€ 400 \mathrm{~m}$ (stg $240 \mathrm{~m}$ ) is envisaged for cross-border co-operation from the Northern Ireland and Republic of Ireland Community Support Frameworks. ${ }^{54}$

With its wide-ranging and complex mandate regarding Structural Funds and Community Initiatives, as well as limited staff and resources, SEUPB faces a number of challenges concerning its ability to balance management and development, all-island and cross-border aspects, as well as its novel position in a multilevel network stretching from the local, grassroots level to the supranational level. ${ }^{55}$ Perhaps because of administrative difficulties and structural complexity, thus far, SEUPB has relied on the Department of Finance and Personnel at Stormont for support in the exercise of its managerial authority, suggesting that an innovative body like SEUPB is more suited to a development role on a cross-border and all-Ireland basis.

49 PEACE II aims to build upon the creative cross-community approaches to funding adopted under PEACE I. Intermediary Funding Bodies (IFBs), which are voluntary and community sector based, continue to play a key role under PEACE II and are projected to be made responsible for the allocation of 34 per cent (approximately stg£100m) of total funds (www.cec.org.uk/ni/funding.pdf).

50 INTERREG III, which is an EU-wide Community Initiative aimed at encouraging indigenous cross-border co-operation in an attempt to off-set the negative effects of EU economic integration for peripheral regions, makes $€ 170 \mathrm{~m}$ (approximately stg $£ 104 \mathrm{~m}$ ) of funding available for Northern Ireland and the border region of the Republic of Ireland.

51 www.northernireland.gov.uk/press/dfp/010620g-dfp.htm

52 www.europe-dfpni.gov.uk

53 www.cec.org.uk

54 Programme for Government 2001.

55 B Laffan and D Payne, Creating Living Institutions: EU Cross-Border Cooperation after the Good Friday Agreement (2001) pp 14-15. 
The operation of the North/South Ministerial Council and Implementation Bodies generally, alongside the other institutions, has been interrupted periodically by major difficulties experienced in the implementation of the Agreement (1998). Indeed, the North/South Ministerial Council has emerged as a first port of call for the exercise of the UUP veto when difficulties are experienced. There have also been inevitable problems involving staff and resource transfer, and the shift of responsibility from central administrations to the novel Implementation Bodies. ${ }^{56}$ These problems have been a factor in the funding gap that has emerged with the delayed implementation of PEACE II and INTERREG III. Although bridging support in the region of $\operatorname{stg} £ 5 \mathrm{~m}$ was provided by a number of Northern Ireland departments, this support did not avert a crisis in the voluntary sector including in the sustainability of many of the voluntary networks and local groups funded through the IFBs under PEACE I. ${ }^{57}$ Consequently, political and institutional change and a shortage of funds posed a major challenge to the future role of the voluntary sector in crossborder development.

Despite the substantial problems, 'live' North/South institutions hold out the prospect of transforming the border from a barrier into a bridge. This is made manifest through ministers and civil servants engaging in the North/South Ministerial Council for the promotion of cross-border cooperation. Consensual decision-making, involving North and South, nationalists and unionists, is understood to be the underlying principle for the operation of the border as a political, economic, social and cultural bridge. One practical application of this principle involves the attendance of two Northern ministers, one with sectoral responsibility and a 'shadow minister' from the other (nationalist or unionist) community, at every sectoral North/South Ministerial Council meeting. ${ }^{58}$ Of course, most Irish nationalists still understand the North/South structures to be important institutional nodes that provide the basis for a fledgling all-Ireland structural framework. Meanwhile, the low-key practical operation of North/South institutions, relatively free from political symbolism, has enabled pro-Agreement unionists to accept cross-border bodies as necessary institutions for political, economic, social and cultural well-being in Northern Ireland, as well as improved relations between unionists and the Republic of Ireland. The sufficient easing of conflict between unionist and nationalist 'truths', resulting from ideological shift on the part of nationalist/republican and proAgreement unionist elites, has been fundamental to the functioning of the border as a bridge between North and South.

\section{Development Prospects}

When one considers past failures and ongoing unionist-nationalist conflict in political and cultural mode, it is something of an achievement that the complicated architecture for cross-border co-operation was established and has operated successfully, even if sometimes in a state of partial shutdown or

56 A Pollak, 'The Policy Agenda for Cross-Border Co-operation: A View from the Centre for Cross-Border Studies' (2001) 49 Administration 15

57 www.niassembly.gov.uk/finance/reports/report3-99rl.htm

58 Pollak op cit $\mathrm{n} 56,16$. 
suspended animation. However, it is the on-going unionist-nationalist political and cultural conflict that weakens the architecture fundamentally, and elements of the unionist political élite in particular that threaten to reestablish the border as a barrier. Development prospects are also affected by the mundane politics of centre-periphery (Belfast/Dublin-North/South) bureaucratic machinations. Another important factor that should not be underestimated in any consideration of development prospects is the relationship between the Ulster unionist community and the Irish state.

The Ulster unionist approach to cross-border co-operation is intimately linked to their political, economic, social and cultural understanding of the Republic of Ireland. In turn, the yardstick of this interpretation is the perceived sense of threat emanating from the South. In 1995, the then UUP MP John D Taylor (now Lord Kilclooney) embarked on a campaign to secure the leadership of his party. Although he was beaten to the leadership by David Trimble, Taylor's campaign marked a significant milestone in the relationship between the Ulster unionist community and the Republic of Ireland. Significantly, Taylor talked at venues throughout the Republic, as well as in Northern Ireland. In his speeches he concentrated on the remit of proposed North/South institutions. Drawing a distinction between 'crossborder' and 'all-Ireland' references ${ }^{59}$ in this context, Taylor argued that the former were acceptable whereas the latter were anathema to unionists. ${ }^{60} \mathrm{He}$ also emphasised the need for unionists to embark upon a co-operative relationship with the SDLP and the Dublin government. Significantly, Taylor sought to challenge the unionist interpretation of the Republic of Ireland as exclusively Catholic and Gaelic when noting 'significant progress towards the creation of a pluralist society free from church control' ${ }^{61}$ Such a challenge signalled the possibility of downgrading the perceived cultural threat emanating from the South.

The 1998 amendment of Articles 2 and 3 of the Irish constitution had the effect of neutralizing the complementary territorial threat for the Ulster unionist community. While unity remains 'the firm will of the Irish nation', 'respect for diversity of . . . identities and traditions' ${ }^{\prime 2}$ suggests that unity does not necessarily imply a unitary state should consent for a 'united Ireland' be forthcoming in the North. ${ }^{63}$ The UUP leader, David Trimble, appeared to recognise this changing Irish state when he endorsed a cooperative North/South approach with the Agreement (1998). However, Trimble has, in political speeches, displayed regressive tendencies in his perception of the Republic of Ireland. For example, in March, 2002, at the annual meeting of the UUP's ruling council in Belfast he exclaimed:

59 The Northern Ireland Programme for Government (2001) settled for the term 'allisland' and used it in conjunction with 'cross-border' to describe the work of the North/South Ministerial Council and Implementation Bodies. (www.pfgni.gov.uk/dec2001pfg/ch6.htm). Here, 'cross-border' may refer solely to 'the border region'.

$60 \mathrm{~J}$ Cash, Identity, Ideology and Conflict: The Structuration of Politics in Northern Ireland (1996) p 216.

61 Irish Times, 28 March 1995.

62 From the new Article 3.1, Constitution of Ireland, 1998.

63 B O'Leary, 'The Character of the 1998 Agreement: Results and Prospects' in R Wilford (ed), Aspects of the Belfast Agreement (2001) p 47 at 67. 
'Contrast the United Kingdom state - a vibrant multi-ethnic, multinational liberal democracy, the fourth largest economy in the world, the most reliable ally of the United States in the fight against international terrorism - with the pathetic sectarian, mono-ethnic, mono-cultural state to our south' ${ }^{64}$ With their cultural references and supremacist overtones, Trimble's remarks suggest that the Catholic, Gaelic-Irish, barbarous and backward stereotype of Ireland and Irishness, as well as the Protestant, reformist, civil and progressive stereotype of the UK and Britishness, still has some currency among pro-Agreement unionists.

Ironically, the leading UUP MP Jeffery Donaldson, who is an equivocal sceptic of the Agreement (1998), was more in sync with the shifting perceptions of Taylor when, in December 2001, he commented:

"You will find today, more so than in 1974 with Sunningdale and the Council of Ireland, that there is less resistance to North/South institutionalized co-operation. That is heavily influenced by changes that have taken place in the Irish Republic. It is seen today as being much less dominated by the Roman Catholic Church, with changes to the constitution that reflect this. It has become a more open society; a more modern society; economically, it is doing very well: all of those things have had an impact here in Northern Ireland and amongst unionists. [We], therefore, feel that perhaps we can do business with the Irish Republic in a manner that will be mutually beneficial. So long as there is recognition of the principle of consent, then the border is going to be there as long as that is the wish of the majority of the population here, but that should not prevent co-operation between two areas that are part of the European Union. It is true that Europe has had an influence here in creating a context within which greater co-operation can take place without people feeling that their sovereignty and identity is being threatened. There is a very delicate balance. If the North/South Ministerial Council and the Implementation Bodies are about co-operation between both parts of this island then I think unionists rest easy." 65

These antithetical remarks suggest that the attitude of UUP élites to crossborder co-operation and the Republic of Ireland is in a state of flux. As Donaldson's comment indicates, the UUP, across both pro- and antiAgreement lines, is the primary site for changing unionist attitudes towards the border. The long-term success of this shift depends on a number of factors, not least, the absence of political and violent threat from Irish nationalism/republicanism and the continuing development of unionist interpretations of a rapidly changing Irish state and society. Meanwhile, DUP élites continue to pay ideological observance to the traditional unionist principles of exclusion regarding Irish nationalists and republicans in

64 Observer, 10 March 2002. Lord Laird of Artigarvan, joint chair of the Languages Implementation Body supported Trimble's assertion claiming: 'There are 25,000 Ulster-Scots people in the Republic who have not had their cultural identity recognized' (Irish News, 11 March 2002).

65 Interview with author, 3 December 2001. 
governance, and the manifestation of the border as a barrier. While this did not preclude their practical involvement in some of the institutions of the Agreement, notably, the Northern Ireland Assembly and Executive, they maintained their boycott of North/South institutions. ${ }^{66}$

\section{CONCLUSION}

Before the 1998 Belfast Good Friday Agreement all efforts directed at creating, or re-creating the border as a bridge to facilitate North/South cooperation were in vain. After the early failures unionists were anxious to maintain the border as a barrier between Northern Ireland and the Republic of Ireland. Constitutional, perfidious and violent threats emanating from the Irish government, the UK government and the IRA respectively, were largely responsible for this preference. The cultural chasm that existed between Ulster unionists and the Irish state also played a significant underlying role. However, contemporary changes in the European state-system, in the BritishIrish intergovernmental relationship, and in the power relationship with Irish nationalists in Northern Ireland are dynamic contemporary factors that have influenced a shift in the ideological position of pro-Agreement unionists. This shift has entailed the inclusion of nationalists and republicans in the governance of Northern Ireland. It has also resulted in the acquiescence of pro-Agreement unionists to institutionalized North/South co-operation and the transformation of the border from barrier to bridge. In no small part, constitutional and cultural changes in the Republic of Ireland have made possible this cross-border co-operation involving pro-Agreement unionists, and to some degree, have neutralized unionist opposition to such cooperation. Nevertheless, four years after the signing of the Agreement their ideological shift remains in a transitional phase and is, therefore, by no means definitive. Consequently, the contemporary political and institutional bridge between North and South exists precariously.

${ }^{66} \mathrm{R}$ Wilford, 'The Assembly and the Executive' in R Wilford (ed), Aspects of the Belfast Agreement (2001) p 107 at 120. 